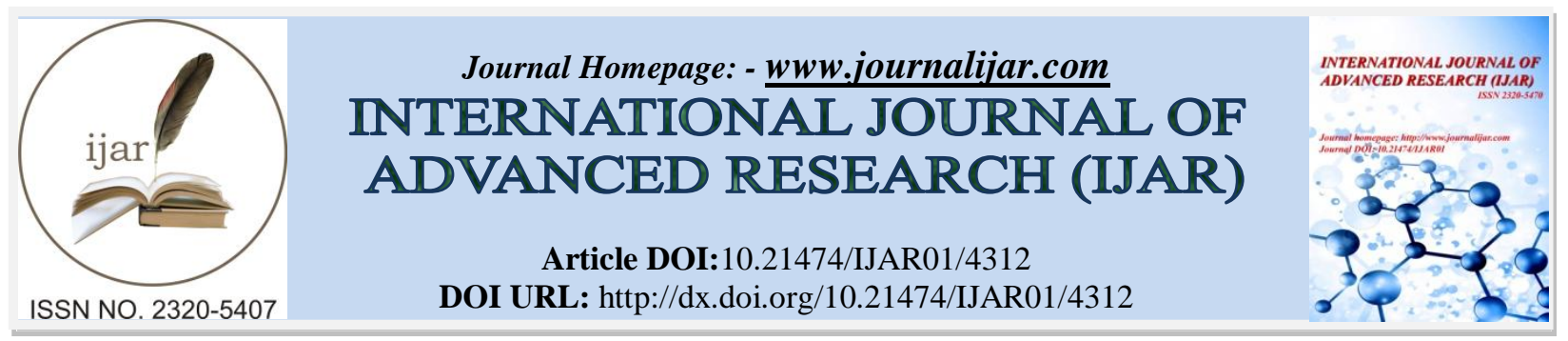

RESEARCH ARTICLE

\title{
THE EFFICIENCY OF MARKETING ON POULTRY CHICKEN WITH INDEPENDENT PATTERN AND PARTNERSHIP PATTERN IN KUBU RAYA DISTRICT, WEST KALIMANTAN.
}

\section{WulanMaulita Indrayana ${ }^{1}$, Budi Hartono ${ }^{2}$ and danBambang Ali Nugroho ${ }^{2}$.}

1. Student in Postgraduate Faculty of Animal Husbandry Brawijaya University Malang, Indonesia.

2. Lecture in Faculty of Animal Husbandry Brawijaya University Malang, Indonesia.

\section{Manuscript Info}

-........................

Manuscript History

Received: 21 March 2017

Final Accepted: 27 April 2017

Published: May 2017

Key words:-

efficiency, chicken marketing, SCP, independent pattern, partnership pattern

\section{Abstract}

The purpose of this study is to assess the level of marketing efficiency in terms of marketing margin, farmer's share, marketing cost share and profit share at each level of independent livestock channel and partnership in Kabupaten Kubu Raya, West Kalimantan. The location of the research is purposive, the respondent of the farmer and the consumers of the sampling method by purposive sampling, while the merchant respondent is taken with snowball sampling. The data used are primary data and secondary data. Data analysis method used is SCP approach, quantitative data analysis through calculation of margin and share value of farmer. The results showed that there are 3 marketing channels that are self-contained channel I that are farmers collecting traders - consumer, II independent pattern channel that is farmer - collector trader - retailer - consumer trader, and marketing channel partnership III pattern that is the core farmer - - merchant retailers - consumers. Farmer's share for the independent pattern I and II is $87.84 \%$ and $87.38 \%$, while the partnership pattern is $83.02 \%$. The efficiency value of self-contained pattern I is 0.03 , independent II is 0,05 , partnership equal to 0,06 so that the most efficient that is in independent pattern I.

Copy Right, IJAR, 2017,. All rights reserved.

\section{Introduction:-}

Livestock is one of agriculture subsector, an interesting business to be studied in breeding sub sector is broiler business. Market prospect and development of broiler agribusiness in Indonesia both upstream subsystem, cultivation subsystem, and downstream subsystem is wide open. Data from Central Bureau of Statistics (2015) shows that the contribution of chicken meat in animal protein consumption pattern from livestock is $66.7 \%$. The dominant proportion of chicken meat consumption is due to its easy availability, relatively affordable prices, improved public consumption awareness, increased income and acceptable characteristics by all levels and segments of Indonesian society.

The Livestock System in Kubu Raya has two systems: independent breeder and partnership breeder system. Arwita (2013) states that the role of breeders is also very decisive to meet the needs of chicken meat supply, for poultry farms can be run with business independently and by cooperating. Broiler farming business that is run by not doing partnership is called independent rancher, all production facilities and infrastructure are fulfilled by the farmers themselves, all the problems and risks in livestock activities are borne personally by the breeder, while the 
partnership pattern is a cooperation between the entrepreneur and the farmer in the effort Management of livestock business and is one way farmers reduce risk. Pattern of partnership there is a division of risk and proportional profit between both parties. Kabupaten Kubu Raya is a potential district in the marketing of broiler meat, due to many traditional markets as a target of chicken meat market and traditional market location that is easy to reach by the people and traditional market distance close to housing.

The marketing of chicken meat distribution requires a marketing agency that works effectively. Mistakes in choosing a distribution channel can make a mistake even in the event of a business distributing the goods and services from producer to consumer. Length of agricultural product marketing channel if not managed properly, causing high cost, good for transaction cost, transportation cost, storage cost, expense of packaging, damage cost and profit of each business sector. An important factor in the system of marketing is the margin and the structure of the trading costs incurred. The trading margin needs to be analyzed to determine the cost, profit and selling price of livestock. Soekartawi (1993) states that marketing efficiency will occur when marketing costs can be reduced so that marketing profits can be higher, the percentage of price differences paid by consumers and producers is not very high, the availability of physical facilities marketing, and the existence of healthy market competition. Qualitative measurement can be done by exposing the marketing that happened so as to see the prosperity of each - each perpetrator of marketing to consumer, while the satisfaction can be done by method of analysis of $\mathrm{S}-\mathrm{C}-\mathrm{P}$ (Structure - Conduct - Performances) (Soekartawi, 2001). The aim of this research is to know the marketing of chicken meat chains, and to see the marketing efficiency level of chicken meat in terms of marketing margin, farmer's share, marketing cost of chicken meat with independent pattern and partnership pattern in Kubu Raya District, especially Rasau Jaya District, West Kalimantan.

\section{Research Methods:-}

The research was conducted in Kabupaten Kubu Raya, especially in Rasau Jaya sub-district, West Kalimantan, from December to January 2017. Site selection was done purposively (purposive method) which location was chosen based on the considerations terinistu, consideration of location selection is because the potential area with the development of livestock relatively large broiler chicken in Kubu Raya Regency based on data from Livestock Office of West Kalimantan Province 2015. Another consideration is that in the sub-district there are two different patterns of broiler farming are the pattern of partnerships and independent patterns so it is more realistic to do comparison analysis of both patterns of exploitation.Three District with the largest population of chicken that is Rasau Jaya District 1.809.067 tail, Sungai Raya 1,705,012 tails, and Kakap River 1,405,090 tails.

\section{Method of collecting Data:-}

Sampling of farmer by using purposive sampling method. Breeders, traders and meat processors are designated as research populations, especially those located in Kubu Raya District, Rasau Jaya Subdistrict, farmer's sample for partnership pattern is taken by following the plot of partnership company, with representative sample of breeder, while for independent breeder is taken sample of breeder from breeders to those in Kubu Raya District especially Rasau Jaya Sub-district, with the largest population in each sub-district. The next data collection is done for the merchants using snowball sampling method (Nugraha, 2006) starting from collectors, wholesalers, intermediate traders and retailers, in order to obtain marketing agency information obtained from each marketing actor so that the flow of marketing becomes coherent and marketing channel can be known, so samples from merchants do not have any specific criteria. Sampling by tracing from collecting merchant, merchant retailer to obtain coherent information and marketing channels can be known. The research data used is primary data through direct interview and secondary data obtained from data of West Kalimantan Livestock Service Office, Animal Husbandry Office of Kubu Raya Regency, Central Bureau of Statistic and publication from related institution, qualitative data analysis through S-C-P analysis approach to know how Efficient marketing of chicken meat in Kubu Raya Regency, and see marketing margins covering farmers' share, cost share, and profit share of each marketing channel.

\section{Research variable:-}

The variables analyzed in this research are chicken meat supply chain which is a form of all chain activity from upstream to downstream in fulfilling consumer needs consisting of transformation and information flow of goods ranging from raw materials to goods to intermediary consumers, by following the flow of marketing Which exist in Kubu Raya area especially Rasau Jaya subdistrict, West Kalimantan pattern of partnership and independent pattern. Efficiency of supply chain of chicken meat by looking at marketing margin, farmer's share, profit, trading cost consisting of transportation cost, retribution, manpower, rent place, equipment and packaging and R / C Ratio, while qualitative data analysis using SCP analysis. 


\section{Data Analysis:-}

The cost structure and margin in chicken supply chain are analyzed by tracing the removal of chicken meat product from producer to final consumer descriptively and using the calculation of margin, percentage of margin, percentage of farmer share, percentage of profit share, percentage of share cost, R / C Ratio, and efficiency value, using the formula:
a. Margin
: Selling Price Seller - Selling Price Breeders
b. Percentage Margin
: (Institutional Margin / Margin Total) x 100\%
c. Share Profit (\%) : ( Institutional Profit / Margin Total ) x 100\%
d. Share Cost : $100 \%$ - Share Profit
e. R / C Ratio : Share Profit / Share Cost
f. Marketing Efficiency consists of:

Efficiency ( E ) : : (Marketing Cost / Chicken Meat Value ) x 100\%

ith condition if

Eps> 1 means inefficient

Eps> 1 means efficient

Farmer Share (\%) : : ( Selling Price of Breeders / Final Agency Sale Price ) x 100\%

Edward, Allen and Shaik (2006) state that behavior and performance (SCP) by looking at output and efficiency as endogenous variables with Battese and Coelli specifications to test the effects of several variables, including risks, market share concentrations and fuel expenditures, to measure profitability effort in the form of efficiency. Measurement of marketing channels with SCP approach can be done qualitatively by looking at the existing market Structure in place, conduct by looking at consumer behavior what the consumer wants, and Performance by looking at turnover, margin, customer satisfaction, etc.

\section{Results and Discussion:-}

Chicken Marketing Channels:-

The result of the research shows that broiler chicken trading channel in Rasau Jaya sub-district involves two institutions of trading, that is collecting merchant and retailer. Broiler chicken trading system in Kecamatan Rasau Jaya generally has several different channels of trading. Based on research conducted in obtaining 3 channels of broiler chicken business in Kecamatan Rasau Jaya, among others, independent channel I that is farmer - Trader Gatherer - Consumer, second channel II is the farmer - collector trader - retailer - consumer, partnership channel III that is farmer - Core - collecting merchants - retailers - consumers.

Cost Structure Analysis of Chicken Ras Pedaging Livestock Business:-

The calculation of cost, income, income and R / C ratio of broiler farm business in Rasau Jaya subdistrict between independent pattern and partnership pattern is presented in full in Table 1.

Table 1:- Comparison of Cost, Revenue and Income of Poultry Breeding Business on Partnership and Independent Pattern in Kecamatan Rasau Jaya in One Period.

\begin{tabular}{|c|c|c|c|c|}
\hline \multirow[t]{2}{*}{ Description } & Independent & & Partnership & \\
\hline & Value (Rp/head) & $\%$ & Value (Rp/head) & $\%$ \\
\hline \multicolumn{5}{|l|}{ FIXED COST } \\
\hline Pen Cage & 63,28 & 0.33 & 57,76 & 0,29 \\
\hline Warehouse & 33,31 & 0.17 & 29,12 & 0,15 \\
\hline Feeding Place & 61,55 & 0.32 & 76,46 & 0,39 \\
\hline Drinking Place & 52,32 & 0.27 & 52,03 & 0,26 \\
\hline Weighing Scale & 3,01 & 0.02 & 2,55 & 0,01 \\
\hline Pump Water & 3,28 & 0.02 & 2,93 & 0,01 \\
\hline Heater & 47,79 & 0.25 & 66,02 & 0,33 \\
\hline Vehicle Maintenance & 63,06 & 0.33 & 57,64 & 0,29 \\
\hline Total Fixed Cost & 327,6 & 1.69 & 344,51 & 1,74 \\
\hline \multicolumn{5}{|l|}{ VARIABLE COST } \\
\hline DOC & $5.645,65$ & 29.15 & $5.866,26$ & 29,62 \\
\hline Feed & $11.139,92$ & 57.52 & $11.359,27$ & 57,35 \\
\hline
\end{tabular}




\begin{tabular}{|l|c|c|c|c|}
\hline Chaff & 179,54 & 0,93 & 164,26 & 0,83 \\
\hline Vaccine+drug & 615,55 & 3,18 & 720,11 & 3,64 \\
\hline Desinfectant & 5,7 & 0,03 & 5,37 & 0,03 \\
\hline Electricity & 89,77 & 0,46 & 85,29 & 0,43 \\
\hline Fuel & 8,21 & 0,04 & 8,16 & 0,04 \\
\hline LPG & 135,5 & 0,70 & 124,87 & 0,63 \\
\hline Labour & $1.218,80$ & 6,29 & 1127,81 & 5,69 \\
\hline Total Variable Cost & $\mathbf{1 7 . 8 1 9 , 8 4}$ & 98,31 & $\mathbf{1 9 . 4 6 1 , 4}$ & 98,26 \\
\hline TOTAL COST & $\mathbf{1 8 . 1 4 7 , 4 4}$ & $\mathbf{1 0 0}$ & $\mathbf{1 9 . 8 0 5 , 9 1}$ & $\mathbf{1 0 0}$ \\
\hline TOTAL RECEIVABLES & $\mathbf{2 2 . 0 0 6 , 0 6}$ & $\mathbf{2 1 . 0 0 0}$ & \\
\hline TOTAL INCOME & $\mathbf{2 . 6 3 9 , 8 2}$ & $\mathbf{1 . 1 9 4 , 0 9}$ & \\
\hline R/C & $\mathbf{1 , 1 3}$ & $\mathbf{1 , 0 6}$ & \\
\hline
\end{tabular}

Results Table 1.shows that the total cost incurred in the production process of one broiler in the independent pattern is lower than the pattern of partnership. The difference between the total cost of the pattern of partnership with the independent pattern reached Rp439.57 per head. This means to produce one broiler in a partnership pattern cost 2.27 percent higher than the costs incurred in the independent pattern. From the composition of fixed costs and variable costs incurred by the breeders of each pattern is not much different. This means for the business of broiler farms, the cost of the most widely issued is the cost for the purchase of feed, DOC, drugs and vaccines, rental and purchase of gas. Cost of feed is only $60 \%$ of the total cost in the maintenance of broiler pattern independent and partnerships due to the short maintenance period of 21-25 days so that feed costs become lower. A short maintenance in the location of this study is caused by consumers in the Kubu Raya and Pontianak districts wanted to make the weight of chicken is not large as that is around $0.9-1.2 \mathrm{~kg}$ per head.

Mulyadi (2005) classifies marketing costs into two groups, namely 1. Order Getting Cost (Cost to get the order), which is all costs incurred in order to obtain an order, for example salary and sales costs, sales and promotion commissions. 2) Order Filling Cost (cost to fulfill the order), that is all expenses incurred in order to get the product to buyer's hand, for example warehousing cost, transportation cost, and billing cost. The total revenue here is equal to the selling price per broiler chicken. Independent pattern farmers get receipts of $\mathrm{Rp} 22.006 .06$ while for breeder partnership pattern is only $\mathrm{Rp} 21.000$. The difference in receipts or selling prices is also due to the contract agreement on the price of output before the production process by participant farmers partnership pattern.

\section{Marketing Efficiency Analysis:-}

Safitri (2009) states that the selling price of a breeder for a commodity varies for each route. The merchant margin is used to determine the difference in income received by each of the trading agencies involved, the greater the margin value of the trade arrangement the greater the revenue of the trading agency and the smaller the farmer's share the farmer receives on the price paid by the end consumer. The calculation of marketing efficiency of broiler chicken in KecamatanRasau Jaya in Kubu Raya District is presented in table 2. 
Table 2:- Marketing Efficiency Analysis of Broiler Chicken in Kecamatan Rasau Jaya Kabupaten Kubu Raya.

\begin{tabular}{|c|c|c|c|c|c|c|}
\hline \multirow[b]{2}{*}{ Marketing Agencies } & \multicolumn{6}{|c|}{ Marketing Channel } \\
\hline & $\begin{array}{l}\text { Channel I } \\
\text { (IDR/bird) }\end{array}$ & 96 & $\begin{array}{l}\text { Channel II } \\
\text { (IDR/bird) }\end{array}$ & 96 & $\begin{array}{c}\text { Channel III } \\
\text { (IDR/bird) }\end{array}$ & $\%$ \\
\hline \multicolumn{7}{|l|}{ Farmer } \\
\hline Production Cost & $19.366,24$ & 77,31 & $19.366,24$ & 76,90 & $19.805,91$ & 78,30 \\
\hline Profit & $2.639,82$ & 10,54 & $2.639,82$ & 10,48 & $1.194,09$ & 4,72 \\
\hline Sale Price & $22.006,06$ & 87,84 & $22.006,06$ & 87,38 & 21.000 & 83,02 \\
\hline \multicolumn{7}{|l|}{ Core Company } \\
\hline Price purchase & & & & & 21.000 & 83,02 \\
\hline Marketing Cost & & & & & 380 & 1,50 \\
\hline Profit & & & & & 605 & 2,39 \\
\hline Margin & & & & & 985 & 3,89 \\
\hline Sale Price & & & & & 21.985 & 86,91 \\
\hline \multicolumn{7}{|l|}{ Redagang pengumpul } \\
\hline Price purchase & $22.006,06$ & 87,84 & $22.006,06$ & 87,38 & 21.985 & 86,91 \\
\hline Marketing Cost & 815 & 3,25 & 805 & 3,20 & 840 & 3,32 \\
\hline Profit & 2.230 & 8,90 & 1.023 & 4,06 & 1.025 & 4,05 \\
\hline Margin & 3.045 & 12,16 & 1.828 & 7,26 & 1.865 & 7,37 \\
\hline Sale Price & $25.051,06$ & 100 & $23.834,06$ & 94,64 & 23.850 & 94,29 \\
\hline \multicolumn{7}{|l|}{ Redagang pengecer. } \\
\hline Price purchase & & & $23.834,06$ & 94,64 & 23.850 & 94,29 \\
\hline Marketing Cost & & & 335 & 1,33 & 360 & 1,42 \\
\hline Profit & & & 1.015 & 4,03 & 1.085 & 4,29 \\
\hline Margin & & & 1.350 & 5,36 & 1.445 & 5,71 \\
\hline Sale Price & & & $25.184,06$ & 100 & 25.295 & 100 \\
\hline Marketing Cost Total & 815 & 3,25 & 1.140 & 4,53 & 1.580 & \\
\hline Profit Total & 2.230 & 8,90 & 2.038 & 8,09 & 2.715 & \\
\hline Margin Total & 3.045 & 12,16 & 3.178 & 12,62 & 4.295 & \\
\hline Farmer share $(96)$ & 87,84 & & 87,38 & & 83,02 & \\
\hline Marketing Eficiencs: & 0,03 & & 0.05 & & 0,06 & \\
\hline
\end{tabular}

The average selling price of broiler chicken in the level of breeder for independent pattern in both marketing channel pattern is $\mathrm{Rp} 22.006,06$ / head whereas in the partnership pattern of $\mathrm{Rp} 21.000$ / head with the average of harvest weight $1,24 \mathrm{~kg}$. While the average purchase price of broilers received by consumers for marketing channel I of Rp. 25.051,06; Marketing channel II of Rp. 25,184,06 and marketing channel III of Rp. 25.295 with average carcass weight per tail 0.9-1 kg. For FGP (Farm Gate Price), the independent livestock farms obtained value of Rp 15,620.17 per head and Rp 14,840.43 for partnership farms, the selling price is above the FGP price so that the farmers do not suffer losses. The total marketing margin that occurred on channel I was Rp 3,045 per head (12.16\%); Channel II of Rp 3,178 per head (12.62\%) and channel III Rp 4,295 per head (16.98\%). The smallest marketing margin of Rp 3,045 per head (12.16\%) is on channel I because the selling price on this channel is lower than the selling price of other channels, while channel III is the marketing channel with the largest total marketing margin of Rp 4,295 per head (16.98\%).

The biggest profit is in channel III which is Rp 2,715 per head (10,73\%) and the smallest profit is in channel I that is $\operatorname{Rp} 2,038$ per head $(8,90 \%)$. This is because the selling price to consumers in channel III is higher than the other channels and the resulting channels are also more so that the largest total marketing cost is in channel III which is Rp 1.580 per head $(6.25 \%)$. The high cost of marketing on channel III is due to there are several marketing institutions so that the treatment of the product more and more. The smallest marketing cost is in channel I which is Rp 815 (3.25\%). This is due to the direct collectors sell to end consumers and their sales volume is small. Farmer's share is highest in the pattern of marketing channel I is $87.84 \%$, while the lowest share of consumer price received 
by farmers occurs in the pattern of marketing channel III (core farmers - collector traders - retail traders consumers), ie $83.02 \%$. Sudiyono (2002) explains that if the price received by producers more than $50 \%$ can be said that the market structure and market information that occurred is not perfect, the condition shows that the marketing system is not efficient.

This happens because of the third marketing channel involves the most marketing agencies when compared to other marketing channels so that the proportion of marketing costs also becomes higher and ultimately affects the proportion that the farmer receives. Based on the value of marketing efficiency that is formed then channel marketing I is a fairly efficient channel with a value of 0.03 EPS. Marketing channel I is a fairly efficient marketing channel because this channel is the marketing agency involved and the least sales volume is compared to channel II and channel III.

\section{Analysis of S - C - P (Structure - Conduct - Performances):- Market Structure:-}

The market structure is a dimension that describes the company's decision-making system, the number of companies in a market, the concentration of the company, the types and differentiation of products and the requirements for entry into the market.

\section{Market Structure at Farmer Level:-}

The market structure faced by broiler breeders in Kecamatan Rasau Jaya has a tendency to approach the oligopoly market. This can be seen from the number of breeders that many compared with the number of institutions that will absorb farmer harvest. This market structure makes the farmers can not affect the price and act as price taker. The trading agency will have a stronger bargaining position because of the lesser number of trading institutions than the farmers. The resulting product is homogeneous live broiler chicken. Breeders at research sites are free to choose to distribute their broiler chickens to any marketing agency.

\section{Market Structure at the Collector Merchant Level:-}

The collector traders in Kecamatan Rasau Jaya numbered 7 people. The market structure faced approached the oligopoly market. This can be seen from the number of sellers who are fewer collectors when compared to the number of buyers that are retailers and consumers. Products that are traded are homogeneous live broiler chicken and broiler chicken meat.

\section{Market Structure at Reseller Wholesaler Level:-}

Retailers face a market structure that tends to approach perfectly competitive markets. This is because of the number of sellers ie retailers and the number of buyers are consumers alike. Products traded are homogenous example of carcasses and retailers can not affect the price at which prices are formed based on market mechanisms. Information on prices is obtained from collecting merchants that supply retailers carcasses.

\section{Market Behavior:-}

Market behavior is the behavior of the trading agencies involved in a channel of trading of a commodity and the trading institutions are adjusting to the market structure in which the trading agencies engage in buying and selling activities, including the form of decisions taken in the face of market structures.

\section{Purchase and Sales Practices of Channel I, II, and III Channels:-}

Broiler breeders in Kecamatan Rasau Jaya on the first commerce channel only conduct sales activities. Collector merchant on channel sales I conduct purchasing activities. Channels of trade arrangements II of the agencies involved are farmers, collecting traders, retailers and consumers. Sales practices between farmers and collecting traders are the same as in channel I trading, but after that broiler broiler collectors are sold to retailers first before finally to the consumer. Channels of trade arrangements III of trading institutions involved include plasma farmers, wholesalers as core companies, collecting traders, retailers and consumers. In this channel the farmer's breeding activities are carried out with a core-plasma partnership system, in which farmers play a role as plasma and wholesalers act as core companies.

\section{System Pricing Channel Price I, II, and III:-}

Farmers on channel sales I can not affect the price and can only act as price taker. Determining the selling price of collecting merchants in Kecamatan Rasau Jaya with direct sales to final consumers is done by following the price 
formed naturally in accordance with the market mechanism (supply and demand broiler). Channel II farmers sell broiler chickens to collecting traders with price determination is done based on the mechanism and price information in the market. The pricing in retailers is determined through the market mechanism that is formed. Channel III plasma farmers can not influence the price setting where the plasma farmer can only act as price taker, the selling price of the carcass determined by the collecting trader is determined based on the market mechanism. The pricing by the retailer in the traditional market is done by following the equilibrium price or the price formed at market.

\section{Interagency Cooperation of Channels I, II, and III:-}

Cooperation between farmers and collecting merchants can be seen through the activities of sales and purchases that they do, cooperation established between collectors with consumer merchant formed because the provision of live broiler chicken by collecting merchants. Cooperation between farmers and collecting traders on channel II is the same as the trading channel I. Cooperation that occurs can be viewed through the activities of sales and purchases made, collaboration between collectors merchants with retailers occurred because collectors provide broiler live or carcass needed by retailer. Cooperation between retailers and consumers occurs when consumers need carcasses from retailers. Cooperation between farmers as plasma and wholesalers as the core of the third trading channel occurs through partnership activities, where the core companies provide livestock production facilities for plasma farmers in Rasau Jaya Sub-district, collaboration between collecting merchants and retailers occurs because collecting traders provide carcass required by retailers, collaboration between retailers and consumers occurs when consumers buy carcasses from retailers.

\section{Conclusions:-}

1. The results of research that has been done then can be obtained conclusion, marketing supply chain in Kubu Raya District, especially in Rasau Jaya District consists of 3 channels, namely: Channel I (Mandiri): Farmer $\rightarrow$ Collector Merchant $\rightarrow$ Consumer. Channel II (Mandiri): Farmer $\rightarrow$ Gatherer Wholesaler $\rightarrow$ Retailer $\rightarrow$ Consumer Channel III (Partnership): Farmers $\rightarrow$ Partnership Partners $\rightarrow$ Retail Merchants $\rightarrow$ Retailers Merchants.

2. Efficiency level analysis results can be seen that the total marketing margin for independent and self-sufficient pattern II is obtained equal to $12.16 \%$, while for partnership of $12.62 \%$, farmer's share for independent patterns I and II is $87.84 \%$ and 87.38 while the pattern of partnership Equal to $83.02 \%$, and efficiency value in each institution that is for independent pattern I efficiency value equal to 0.03 , independent pattern II efficiency value equal to 0.05 , and for partnership pattern equal to 0.06 so that, the most efficient that is independent pattern I because of the marketing agency is only a few so that the necessary of marketing costs are not so large.

\section{Bibliography:-}

1. Arwita, P . 2013. AnalisisRisiko Usaha PeternakanAyam Broiler DenganPolaKemitraandanMandiri di Kota Sawahlunto / KAB. Sijunjung.Skripsi.FakultasEkonomidanManajemenInstitutPertanian Bogor.

2. BadanPusatStatistikKabupatenKubu Raya. 2015. KabupatenKubu Raya DalamAngka. Laporan BPS KabupatenKubu Raya.

3. Edwad, S , Allen A. J danShaik, S . 2006 .Market Structure Conduct Performance ( SCP ) Hypotesis Revisited using Stochastic Frontier Efficiency Analysis. Selected Paper Presented at the American Agricultural Economics Association Annual Meeting . Long Beach, Clifornia , July 23 - 262006.

4. Istiyanti, $\quad$ Eni. $2010 . \quad$ EfisiensiPemasaranCabaiMerahKeriting $\quad$ Di KecamatanNgemplakKabupatenSleman. Mapeta, 12(2): 116-124.

5. Mulyadi. 2005. Akuntansi Biaya. edisi 5. Aditya Media.: Yogyakarta.

6. Nugraha $2006 \quad$ AnalisisEfisiensiPemasaranJamurTiram $\quad$ Segar. Skripsi.FakultasPertanianInstitutPertanianBogor .

7. Safitri, B. 2009.AnalisisTataniagaTelurAyamKampung (StudiKasus :Kabupaten Bogor, ProvinsiJawa Barat) .Skripsi. DepartemenAgribisnisFakultasEkonomidanManajemenInstitutPertanian Bogor. Bogor.

8. Soekartawi. 2001. Analisis Usaha Tani. Universitas Indonesia ( UI - Press ). Jakarta.

9. Soekartawi.1993. ManajemenPemasaranDalamBisnis Modern.PustakaHarapan. Jakarta.

10. Sudiyono . 2002. PemasaranPertanian .UniversitasMuhammadiyah Malang. Malang. 